A Short Note on Economic Development and Socioeconomic Inequality in Female Body Weight

Sofie J. Cabus, Eva Deuchert, Darjusch Tafreschi

February 2012 Discussion Paper no. 2012-04 


$\begin{array}{ll}\text { Editor: } & \text { Martina Flockerzi } \\ & \text { University of St. Gallen } \\ & \text { School of Economics and Political Science } \\ & \text { Department of Economics } \\ & \text { Varnbüelstrasse 19 } \\ & \text { CH-9000 St. Gallen } \\ & \text { Phone +41 71 224 23 25 } \\ & \text { Fax } \quad+41712243135 \\ & \text { Email seps@unisg.ch } \\ & \text { School of Economics and Political Science } \\ & \text { Department of Economics } \\ & \text { University of St. Gallen } \\ & \text { Varnbüelstrasse 19 } \\ \text { Publisher: } & \text { CH-9000 St. Gallen } \\ & \text { Phone +41 71 224 23 25 } \\ & \text { Fax +41 71 224 31 35 } \\ & \text { http://www.seps.unisg.ch }\end{array}$




\section{A Short Note on Economic Development and Socioeconomic Inequality in Female Body Weight ${ }^{1}$}

Sofie J. Cabus, Eva Deuchert, Darjusch Tafreschi

Author's address:

Prof. Dr. Eva Deuchert

CDI-HSG

Rosenbergstrasse 51

$\mathrm{CH}-9000$ St Gallen

Phone +41712242318

Fax +41712243290

Email Eva.Deuchert@unisg.ch

Website www.cdi.unisg.ch

Sofie J. Cabus

Maastricht University

TIER

Kapoenstraat 2

NL-6200 Maastricht

Darjusch Tafreschi

SEW-HSG

Varnbüelstrasse 14

$\mathrm{CH}-9000$ St. Gallen

Email Darjusch.Tafreschi@unisg.ch

Website www.sew.unisg.ch

\footnotetext{
1 This draft: February 201. Please do not quote and do not circulate this draft without permission of one of the authors. Comments are very welcome.

We would like to thank Eddy van Doorslaer, Uwe Sunde and Erik Schokkaert for useful comments on an earlier version of this paper. All remaining errors are, of course, ours.
} 


\begin{abstract}
The origin of the obesity epidemic in developing countries is still poorly understood. It has been prominently argued that economic development provides a natural interpretation of the growth in obesity. This paper tests the main aggregated predictions of the theoretical framework to analyze obesity: Average female body weight is associated with economic development. In relatively poor countries, obesity is a phenomenon of the socioeconomic elite. With economic development, obesity shifts towards individuals with lower socioeconomic status.
\end{abstract}

\title{
Keywords
}

Obesity, socioeconomic inequality, economic development.

\section{JEL Classification}

11. 


\section{Introduction}

The obesity epidemic has attracted considerable attention in recent years. Much of the related research has focused on obesity in developed countries (see for example French et al. (2010), Baum (2009); Baum \& Ruhm (2009); Chou, Grossman, \& Saffer (2008); Gruber \& Frakes (2006) among others), where the emerging epidemic in developing countries has attracted less attention (Abdulai, 2010; Sahn, 2009; Doak \& Popkin, 2008; Asfaw, 2007).

Philipson and co-authors (Lakdawalla \& Philipson, 2009; Lakdawalla, Philipson, \& Bhattacharya, 2005; Philipson \& Posner, 2003) provide a theoretical framework to analyze the obesity epidemic. They argue that economic development provides a natural interpretation for the emerging obesity epidemic and that on the individual level, a non-monotonic relationship between income and weight arises, with obesity concentrated among the socioeconomic elite in poor countries and among the poor in more developed countries.

Empirical evidence supporting the theoretical predictions comes mainly from single country studies analyzing socioeconomic inequality in body weight (such as in Tafreschi (2011) for example), whose results are difficult to generalize, or from literature reviews. These reviews document that in developing countries obesity was initially a disease of the rich (McLaren, 2007; Sobald \& Stunkard, 1989). More recently, obesity shifted from the socioeconomic elite to people with a relatively lower socioeconomic status (SES) (Monteiro, Moura, Conde, \& Popkin, 2004). However, the number of reviewed studies is relatively small, included studies use very different indicators to measure socioeconomic status (such as education, income, wealth, etc.) and reviews are based on a great variety of study populations (general population, immigrants, populations from selected areas, etc.).

This paper is, to the best of our knowledge, the first systematic overview of the SESobesity gradient in developing countries. We contribute to the literature from four angles: We use (1) comparable micro-data (Demographic Health Surveys), (2) comparable samples 
(women drawn from the general population), (3) similar indicators for SES-rank, and (4) data from more than 50 developing countries. Our results confirm the main predictions of the theoretical contribution of Philipson and co-authors.

\section{Theoretical background}

Philipson and co-authors (Lakdawalla \& Philipson, 2009; Lakdawalla, Philipson, \& Bhattacharya, 2005; Philipson \& Posner, 2003) analyze the long-run rise in obesity in a standard micro-economic framework, where body weight is a commodity produced with chosen inputs (calorie consumption and physical exercise). In their theoretical framework, body weight is influenced by three exogenous factors, i.e. (1) the relative food price, (2) the calories expended per hour of work, and (3) the individual wage rate.

Economic development is likely to affect all of these three factors. First, with economic development, relative food prices decline. Second, technological change alters the industry structure. Fewer people are needed for food production, while other sectors, particularly the service sector, become more relevant. Work becomes more sedentary and, hence, individuals need fewer calories to perform in their jobs. Third, technological progress increases productivity and with this also wages. These three factors would lead to a higher demand for calories and higher body weight, particularly among wealthier people. On the other hand, individuals have preferences for an ideal weight. If an ideal weight is a normal good, the marginal disutility of deviating from this ideal weight is higher for higher income groups. This results in a negative association between socio-economic status and body weight.

Whether or not one observes a positive or negative income gradient of overweight in a population depends largely on the level of economic development. In relatively poor countries, the first effect dominates and one would expect a positive relationship between SES and body weight. In more advanced countries, the second (disutility) effect dominates for at 
least some proportion of the population and the relation between SES and weight is inverted U-shaped.

Ideally one would like to empirically test this theory by estimating the causal impact of absolute SES on body weight, either on different parts of the income distribution to analyze effect heterogeneity within a country, or across different countries to compare effects. This is, however, difficult for two reasons: (1) Measuring incomes (as a measure for absolute SES) is problematic (Pyatt, 2003) and many household surveys include measures for relative SESrank but not for absolute SES. (2) A creditable identifying strategy is needed to isolate the impact of SES on body weight, but exogenous variations of SES are rare. We therefore test for two predictions at the aggregate level that follow from the micro-economic predictions.

Proposition 1: Average body weight is associated with economic development.

Denote the relationship between body weight and income with $W=g(x)$ and the probability density function of income with $f(x)$. Economic development shifts the income distribution function to $f^{*}(x)$ such that the average income increases $\int x f(x) d x<$ $\int x f^{*}(x) d x$. As long as $g(x)$ is a strictly positive transformation (or in other words, if higher incomes lead to higher body weight), economic development should be associated with higher average weight (i.e. $\int g(x) f(x) d x<\int g(x) f^{*}(x) d x$ ). The disease is self-limiting, however, if the disutility effect dominates for at least a some share of the population. If this is the case, economic development can be associated with constant or even declining average weight (i.e. $\left.\int g(x) f(x) d x \geq \int g(x) f^{*}(x) d x\right)$. We, thus, expect a non-linear (and maybe even non-monotonic) relationship between average weight and economic development.

One should notice that with a non-linear individual level relationship between body weight and SES, aggregate cross-section studies may be subject to the aggregation problem (see the discussion on the Wilkinson hypothesis such as in Wildman (2001) for example). It may thus 
be difficult to infer on individual behavior from aggregated data. We therefore combine micro-level (i.e., the SES-related inequality within a country) and macro-level evidence.

Proposition 2: SES-related health inequality is associated with economic development.

Denote the cumulative proportion of body weight with $q_{W}(x)=\frac{1}{E[g(X)]} \int_{0}^{x} g(X) f(X) d X$ and the cumulative income distribution with $p(x)$. The concentration curve $L_{W}(p)$ denotes the relationship between $q_{W}(x)$ and $p(x)$, and indicates the proportion of weight in individuals with incomes less than or equal to $x$. The concentration index is twice the area between the concentration curve and the line of equality (Wagstaff, Paci, \& van Doorslaer, 1991). If the relationship between body weight and income is differentiable, the resulting second derivate of the concentration curve is equal to (Podder \& Tran-Nam, 1994):

$$
L_{W}^{\prime \prime}(p)=\frac{g^{\prime}(x)}{E[g(X)] f(x)}
$$

Suppose that on the individual level, higher incomes lead to higher body weight (i.e. $g^{\prime}(x)>0$ for all plausible incomes), the concentration curve is convex (the concentration index takes positive values). If in contrast, higher incomes would lead people to lose weight (i.e. $g^{\prime}(x)<0$ for all plausible incomes), the concentration curve is concave (the concentration index takes negative values). In the intermediate case, where the relationship between income and weight is inverted U-shaped, the concentration curve crosses the equality line (see Figure 1).

\section{[Figure 1: HERE]}

Note that in standard applications, concentration index is often used to rank countries. Concentration curves that cross the line of equality make it difficult to judge which country has a more unequal health distribution. In this application, concentration indices are used to test the implication of a theoretical model, where crossing concentration curves are part of this 
theory. We expect a negative association between the concentration index and economic development, with concentration indices close to zero in more advanced economies.

\section{Empirical analysis}

\subsection{Data}

To test the two propositions outlined above, we use the Demographic and Health Surveys (DHS), which are nationally representative household surveys. These cross-sectional surveys typically include 5,000 to 30,000 households, and provide anthropometric measurement (weight and height) for a selected sample of women. We use DHS data from 52 different countries from 1990 to 2008 (in total 115 different surveys, including information from 943'605 women).

To test proposition 1, average Body Mass Index $\left(B M I=k g / \mathrm{m}^{2}\right)$, proportion of the population being overweight or obese $(B M I \geq 25)$ or obese $(B M I \geq 30)$ is used as dependent variable. The concentration index (Kakwani, Wagstaff, \& van Doorslaer, 1997) based on the DHS wealth index (Rutstein, 2008; Filmer \& Pritchett, 2001) is used as dependent variable to test proposition 2. Our main independent variable approximating economic development is per capita GDP, which ranges between US\$ 125 and 5'155. Descriptive statistics of all dependent and independent variables are provided in the appendix.

\subsection{Results}

We run a regression of per capita GDP on average BMI (alternatively the share with overweight or obesity) to test for proposition 1. A squared term of per capita GDP is included to capture a potential non-linear relationship. Controlling for a linear time trend (Table 1 , column 1) shows that average BMI, as well as overweight or obesity rates significantly 
increase with economic development. The results are robust to controlling for confounding variables on the aggregated level (see columns 2-4).

\section{[Table 1: HERE]}

To test for proposition 2, we a run a regression of per capita GDP, its squared term and a linear time trend on the concentration indices for BMI (alternatively, concentration indices for overweight or obesity). As predicted by the theory, our results indicate a significantly negative association between the concentration indices for overweight and obesity and per capita GDP (Table 2). The association between the concentration indices for BMI and per capita GDP is also negative but not significant on standard levels $(\mathrm{p}=0.15)$. The results are robust to including control variables on the aggregated level (see columns 2-4). This sustains to the second hypothesis that obesity shifts from the socioeconomic elite to people with a relatively low socioeconomic status with ongoing economic development.

\section{[Table 2: HERE]}

Several sensitivity checks are performed to support our main findings. The results are not reported but available from the authors upon request. First, we run a demographic standardization (Kakwani, Wagstaff, \& van Doorslaer, 1997) to account for the heterogeneity in the population structure. Included variable in this standardization are age, pregnancy status, marital status, type of residence, number of children aged below 5 and total number of children ever born. All of these factors are very likely associated with body weight for women, and may be also associated with the development status of the country. Second, DHS surveys for more than one year are available for 35 countries allowing estimating time fixed effects panel models. This allows controlling for any time-fixed confounders, such as for cultural differences. Third, we address for the fact that overweight and obesity are binary variables. This is particularly a problem since concentration indices are bounded by the mean of the health variable with binary variables. Since the theory predicts increasing average obesity 
levels with ongoing economic development for developing countries, lower concentration indices could simply reflect higher average obesity levels and may not portray lower SESrelated inequality. We therefore normalize the concentration index by dividing it by its feasible minimum or maximum (Wagstaff A. , 2011). And finally, we use alternative measures for the relative SES-rank to adjust for the fact that our results may be sensitive to the choice or our measure for SES (Wagstaff \& Watanabe, 2003). The DHS wealth index does not use the same asset types in all countries. We thus construct an alternative asset index that uses the same types of asset. This, however, does not solve the incomparability problem (i.e. the ownership of certain assets may not correspond to a similar SES-rank in different countries). We also use the highest education of the household head as an indicator for SESrank (even in culturally and economically diverse countries, higher education should lead to higher incomes and thus higher SES-rank). Our results are robust to all these sensitivity checks.

\section{Conclusions}

This paper analyses the socioeconomic gradient in obesity in developing countries. Our results indicate that economic development is positively associated with average body weight, and that economic development also determines the distribution of body weight within countries. These results are consistent with a theoretical model that supports ideal weight preferences.

Nonetheless, the results are worrisome. If the observed trend continues, the obesity epidemic may further burden health systems in developing countries, which are already challenged by the spread of communicable diseases. Further research should outline the effectiveness of public health prevention campaigns in schools, communities and beyond. 


\section{References}

Abdulai, A. (2010). Socio-economic Characteristics and Obesity in Underdeveloped Economies: Does Income Really Matter? Applied Economics, 42(1-3), pp. 157-169.

Asfaw, A. (2007). Do Government Food Price Policies Affect the Prevalence of Obesity? Empirical Evidence from Egypt. World Development, 35(4), pp. 687-701.

Baum, C. (2009). The Effects of Cigarette Costs on BMI and Obesity. Health Economics, 18(1), pp. 3-19.

Baum, C., \& Ruhm, C. (2009). Age, Socioeconomic Status and Obesity Growth. Journal of Health Economics, 28(3), pp. 635-648.

Chou, S.-Y., Rashad, I., \& Grossman, M. (2008). Fast-Food Restaurant Advertising on Television and Its Influence on Childhood Obesity. Journal of Law and Economics, 51(4), pp. 599-618.

Doak, C. M., \& Popkin, B. M. (2008). The Rapid Emergence of Obesity in Developing Countries. In N. Totowa, Nutrition and Health in Developing Countries, Second edition (pp. 617-638). Springer, Humana Press.

Filmer, D., \& Pritchett, L. (2001). Estimating wealth effects without expenditure data—or tears: An application of educational enrollment in states of India. Demography, 38(1), pp. 115-132.

French, M., Norton, E., Fang, H., \& Maclean, J. (2010). Alcohol Consumption and Body Weight. Health Economics, 7, pp. 814-832.

Gruber, J., \& Frakes, M. (2006). Does Falling Smoking Lead to Rising Obesity? Journal of Health Economics, 25(2), pp. 183-97.

Kakwani, N., Wagstaff, A., \& van Doorslaer, E. (1997). Socioeconomic Inequalities in Health: Measurement, Computation and Statistical Inference. Journal of Econometrics, 77(1), pp. 87-104.

Lakdawalla, D., \& Philipson, T. (2009). The Growth of Obesity and Technological Change. Economics and Human Biology, 7(3), pp. 283-293.

Lakdawalla, D., Philipson, T., \& Bhattacharya, J. (2005). Welfare-Enhancing Technological Change and the Growth of Obesity. American Economic Review, 95(2), pp. 253-257.

McLaren, L. (2007). Socioeconomnic Status and Obesity. Epidemiologic Reviews, 29, pp. 2948 .

Monteiro, C., Moura, E., Conde, W., \& Popkin, B. (2004). Socioeconomic status and obesity in adult populations of developing countries: a review. Bull World Health Organ, 82(12), pp. 940-946.

Philipson, T., \& Posner, R. (2003). The Long Run Growth of Obesity as a Function of Technological Change. Perspectives in Biology and Medicine, 46(3), pp. 87-108.

Podder, N., \& Tran-Nam, B. (1994). A New Approach to Estimating Engel Elasticities from Concentration Curves. Oxford Economic Papers, 46(2), pp. 262-276.

Pyatt, G. (2003). Development and the Distribution of Living Standards: A Critique of the Evolving Data Base. Review of Income and Wealth, 3(49), pp. 333-358.

Rutstein, S. (2008). The DHS Wealth Index: Approaches for Rural and Urban Areas. Calverton, Maryland, USA: Macro International Inc. 
Sahn, D. E. (2009). Weights on the rise: where and for whom? Journal of Economic Inequality, 7(4), pp. 351-370.

Sobald, J., \& Stunkard, A. (1989). Socioeconomic Status and obesity: a review of the literature. Psychol Bull, 105, pp. 260-275.

Tafreschi, D. (2011). The Income Body Weight Gradients in the Developing Economy of China. University of St. Gallen.

Wagstaff, A. (2011). The concentration index of a binary outcome revisited. Health Economics, 20(10), pp. 1155-1160.

Wagstaff, A., \& Watanabe, N. (2003). What Difference Does the Choice of SES Make in Health Inequality Measurement? Health Economics, 12(10), pp. 885-890.

Wagstaff, A., Paci, P., \& van Doorslaer, E. (1991). On the measurement of inequalities in health. Social Science \& Medicine, 33(5), pp. 545-557.

Wildman, J. (2001). The impact of income inequality on individual and societal health: absolute income, relative income and statistical artefacts. Health Economics, 10(4), pp. 357-361. 


\section{Figures}

\section{Figure 1: Concentration curves}

\section{Cumulative share of body weight}

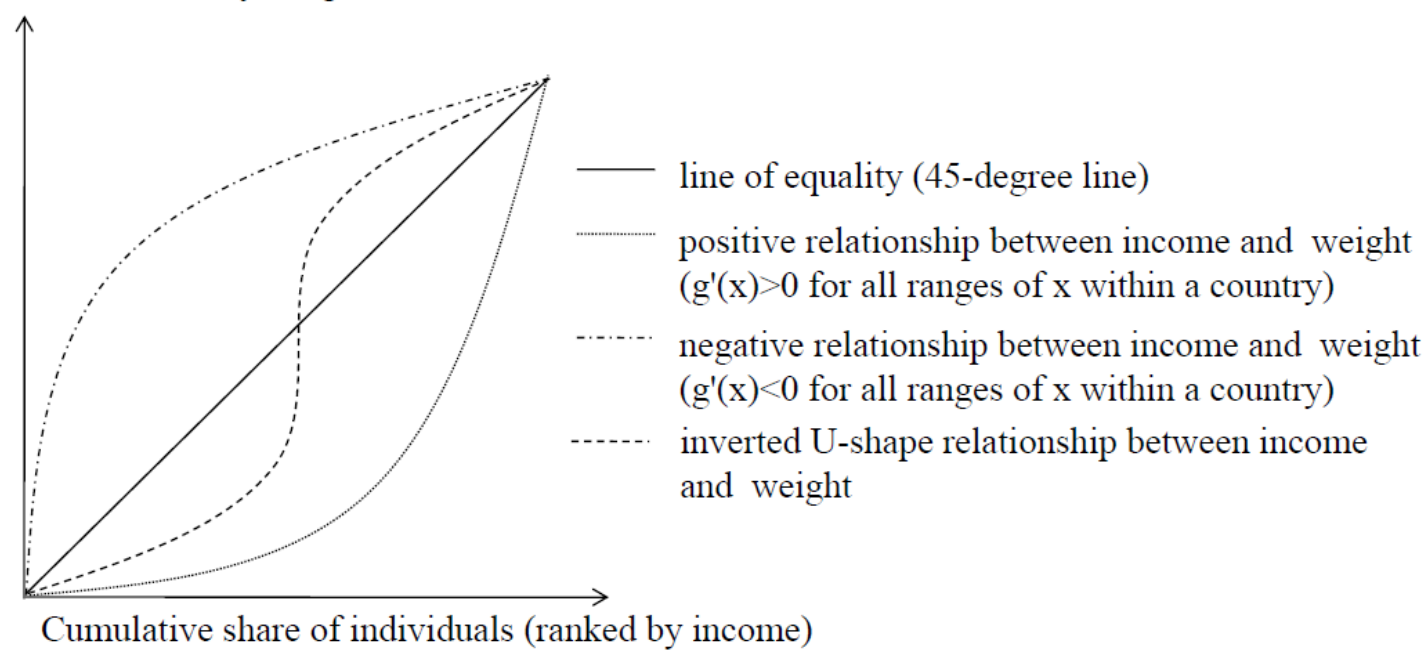




\section{Tables}

Table 1: Estimation results for proposition 1 (per capita GDP in thousands).

\begin{tabular}{|c|c|c|c|c|c|c|c|c|c|}
\hline & & Model 1 & & Model 2 & & Model 3 & & Model 4 & \\
\hline \multirow[t]{2}{*}{ Body mass } & GDP & $\begin{array}{r}4.13770 \\
(0.46460)\end{array}$ & $* * *$ & $\begin{array}{r}3.67630 \\
(0.50190)\end{array}$ & $* * *$ & $\begin{array}{r}3.61730 \\
(0.52040)\end{array}$ & $* * *$ & $\begin{array}{r}3.83820 \\
(0.53640)\end{array}$ & $* * *$ \\
\hline & GDP SQ & $\begin{array}{r}-0.00074 \\
(0.00012)\end{array}$ & $* * *$ & $\begin{array}{r}-0.00065 \\
(0.00012)\end{array}$ & $* * *$ & $\begin{array}{r}-0.00063 \\
(0.00013)\end{array}$ & $* * *$ & $\begin{array}{r}-0.00068 \\
(0.00013)\end{array}$ & $* * *$ \\
\hline \multirow[t]{2}{*}{$\%$ Overweight } & GDP & $\begin{array}{r}0.35660 \\
(0.03720)\end{array}$ & $* * *$ & $\begin{array}{r}0.31360 \\
(0.03970)\end{array}$ & $* * *$ & $\begin{array}{r}0.31460 \\
(0.04100)\end{array}$ & $* * *$ & $\begin{array}{r}0.33140 \\
(0.04160)\end{array}$ & $* * *$ \\
\hline & GDP SQ & $\begin{array}{r}-0.00006 \\
(0.00001)\end{array}$ & $* * *$ & $\begin{array}{r}-0.00005 \\
(0.00001)\end{array}$ & $* * *$ & $\begin{array}{r}-0.00005 \\
(0.00001)\end{array}$ & $* * *$ & $\begin{array}{r}-0.00006 \\
(0.00001)\end{array}$ & $* * *$ \\
\hline \multirow[t]{2}{*}{ \% Obesity } & GDP & $\begin{array}{r}0.15440 \\
(0.02320)\end{array}$ & $* * *$ & $\begin{array}{r}0.13270 \\
(0.02390)\end{array}$ & $* * *$ & $\begin{array}{r}0.13340 \\
(0.02540)\end{array}$ & $* * *$ & $\begin{array}{r}0.13660 \\
(0.02620)\end{array}$ & $* * *$ \\
\hline & GDP SQ & $\begin{array}{r}-0.00003 \\
(0.00001)\end{array}$ & $* * *$ & $\begin{array}{r}-0.00002 \\
(0.00001)\end{array}$ & $* * *$ & $\begin{array}{r}-0.00002 \\
(0.00001)\end{array}$ & $* * *$ & $\begin{array}{r}-0.00002 \\
(0.00001)\end{array}$ & $* * *$ \\
\hline $\begin{array}{l}\text { Control } \\
\text { variables }\end{array}$ & & Time trend & & $\begin{array}{l}\text { Time trend } \\
\text { Urbanizatio }\end{array}$ & & $\begin{array}{l}\text { Time trend } \\
\text { Urbanizatior } \\
\text { Population }\end{array}$ & & $\begin{array}{l}\text { Time trend } \\
\text { Urbanization } \\
\text { Population } \\
\text { CPI } \\
\end{array}$ & \\
\hline Obs. & & 115 & & 115 & & 115 & & 108 & \\
\hline
\end{tabular}

Note: Robust standard errors clustered at the country level in brackets. Star levels denote significant levels at (*) $10 \%,(* *) 5 \%$ and $(* * *) 1 \%$. 
Table 2: Estimation results for proposition 2 (per capita GDP in thousands).

\begin{tabular}{|c|c|c|c|c|c|c|c|c|c|}
\hline & & Model 1 & & Model 2 & & Model 3 & & Model 4 & \\
\hline \multirow[t]{2}{*}{ Body mass } & GDP & $\begin{array}{r}-0.00432 \\
(0.00273)\end{array}$ & & $\begin{array}{r}-0.00150 \\
(0.00325)\end{array}$ & & $\begin{array}{r}-0.00070 \\
(0.00318)\end{array}$ & & $\begin{array}{r}-0.00287 \\
(0.00335)\end{array}$ & \\
\hline & GDP SQ & $\begin{array}{r}0.00000 \\
(0.00000)\end{array}$ & & $\begin{array}{r}0.00000 \\
(0.00000)\end{array}$ & & $\begin{array}{r}0.00000 \\
(0.00000)\end{array}$ & & $\begin{array}{r}0.00000 \\
(0.00000)\end{array}$ & \\
\hline \multirow[t]{2}{*}{ Overweight } & GDP & $\begin{array}{r}-0.21340 \\
(0.02790)\end{array}$ & $* * *$ & $\begin{array}{r}-0.17010 \\
(0.03430)\end{array}$ & $* * *$ & $\begin{array}{r}-0.15940 \\
(0.03280)\end{array}$ & $* * *$ & $\begin{array}{r}-0.18880 \\
(0.03360)\end{array}$ & $* * *$ \\
\hline & GDP SQ & $\begin{array}{r}0.00003 \\
(0.00001)\end{array}$ & $* * *$ & $\begin{array}{r}0.00003 \\
(0.00001)\end{array}$ & $* * *$ & $\begin{array}{r}0.00002 \\
(0.00001)\end{array}$ & $* * *$ & $\begin{array}{r}0.00003 \\
(0.00001)\end{array}$ & $* * *$ \\
\hline \multirow[t]{2}{*}{ Obesity } & GDP & $\begin{array}{r}-0.31610 \\
(0.03850)\end{array}$ & $* * *$ & $\begin{array}{r}-0.23410 \\
(0.04440)\end{array}$ & $* * *$ & $\begin{array}{r}-0.22520 \\
(0.04390)\end{array}$ & $* * *$ & $\begin{array}{r}-0.26010 \\
(0.04570)\end{array}$ & $* * *$ \\
\hline & GDP SQ & $\begin{array}{r}0.00005 \\
(0.00001)\end{array}$ & $* * *$ & $\begin{array}{r}0.00003 \\
(0.00001)\end{array}$ & $* * *$ & $\begin{array}{r}0.00003 \\
(0.00001)\end{array}$ & $* * *$ & $\begin{array}{r}0.00004 \\
(0.00001)\end{array}$ & $* * *$ \\
\hline $\begin{array}{l}\text { Control } \\
\text { variables }\end{array}$ & & Time trend & & $\begin{array}{l}\text { Time trend } \\
\text { Urbanizati }\end{array}$ & & $\begin{array}{l}\text { Time trend } \\
\text { Urbanizatio } \\
\text { Population }\end{array}$ & & $\begin{array}{l}\text { Time trend } \\
\text { Urbanizatio } \\
\text { Population } \\
\text { CPI }\end{array}$ & \\
\hline Obs. & & 100 & & 100 & & 100 & & 93 & \\
\hline
\end{tabular}

Note: Robust standard errors clustered at the country level in brackets. Star levels denote significant levels at $(*)$ $10 \%,(* *) 5 \%$ and $(* * *) 1 \%$. 


\section{Appendix}

Table A1: Descriptive statistics for dependent variables

\begin{tabular}{lrrrrr}
\hline & Obs & Mean & Std. Dev. & \multicolumn{1}{c}{ Min } & \multicolumn{1}{c}{ Max } \\
\hline & & & & & \\
Average BMI & 115 & 23.067 & 2.164 & 18.92 & 29.846 \\
Concentration index (BMI) & 100 & 0.0197 & 0.0107 & -0.0064 & 0.0388 \\
& & & & & \\
Share with BMI>25 (overweight) & 115 & 0.256 & 0.1809 & 0.0195 & 0.7899 \\
Concentration index (overweight) & & & & & \\
& 115 & 0.0811 & 0.0881 & 0.001 & 0.4469 \\
Share with BMI>30 (obese) & 100 & 0.35 & 0.2061 & -0.0409 & 0.8332 \\
Concentration index (obese) & & & & & \\
\hline
\end{tabular}


Table A2: Descriptive statistics for independent variables at the aggregated level

\begin{tabular}{lrrrrr}
\hline Variable & Obs & Mean & Std. Dev. & Min & Max \\
\hline & & & & & \\
Time (year) & 115 & 2000 & 5 & 1991 & 2008 \\
Per capita GDP (\$) & 115 & 930.96 & 1020.5 & 124.85 & 5115.1 \\
Urbanization (rates) & 115 & 3.4348 & 1.9170 & -2.5251 & 14.993 \\
Population (thousands) & 115 & 37,500 & 106,000 & 497 & $1,090,000$ \\
Consumer Price Index & 108 & 73.634 & 32.38366 & 0.0501 & 143.11 \\
& & & & &
\end{tabular}

